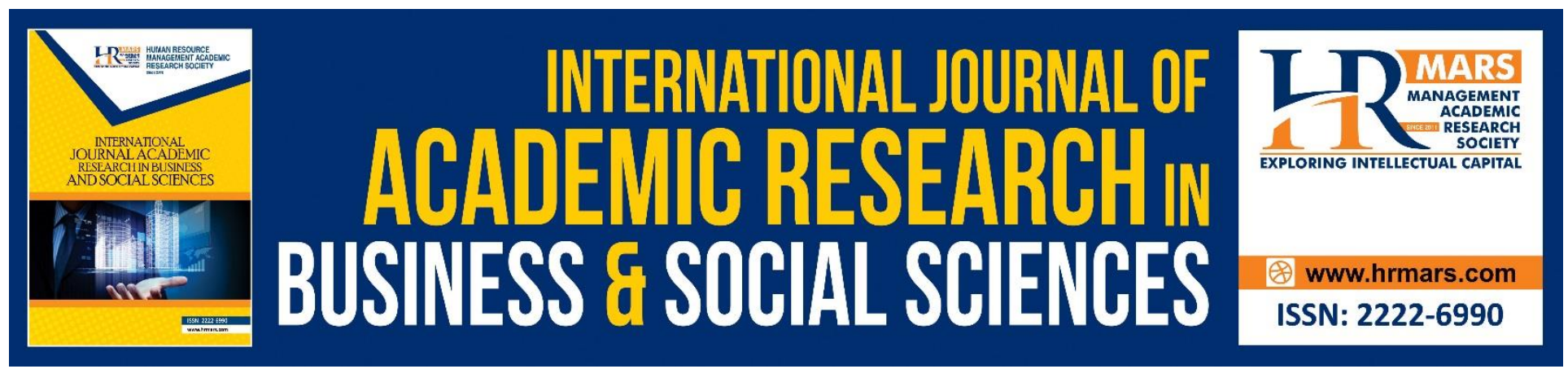

\title{
The Role of Socio-Political Environment in Business Success: A Case of Small Businesses in Uganda
}

Olema Hamiza, Takwi Mbah Francis, Taban Rashid.

To Link this Article: http://dx.doi.org/10.6007/IJARBSS/v10-i10/8006

DOI:10.6007/IJARBSS/v10-i10/8006

Received: 21 August 2020, Revised: 07 September 2020, Accepted: 27 September 2020

Published Online: 29 October 2020

In-Text Citation: (Hamiza, Francis, \& Rashid, 2020)

To Cite this Article: Hamiza, O., Francis, T. M., \& Rashid, T. (2020). Attitudes towards Local Anaesthetic Simulator

Kit as a Novel Teaching Aid. International Journal of Academic Research in Business and Social Sciences.

10(10), 783-799.

Copyright: (C) 2020 The Author(s)

Published by Human Resource Management Academic Research Society (www.hrmars.com)

This article is published under the Creative Commons Attribution (CC BY 4.0) license. Anyone may reproduce, distribute, translate and create derivative works of this article (for both commercial and non-commercial purposes), subject to full attribution to the original publication and authors. The full terms of this license may be seen

at: $\underline{\text { http://creativecommons.org/licences/by/4.0/legalcode }}$

Vol. 10, No. 10, 2020, Pg. 783 - 799

http://hrmars.com/index.php/pages/detail/IJARBSS

JOURNAL HOMEPAGE

Full Terms \& Conditions of access and use can be found at http://hrmars.com/index.php/pages/detail/publication-ethics 


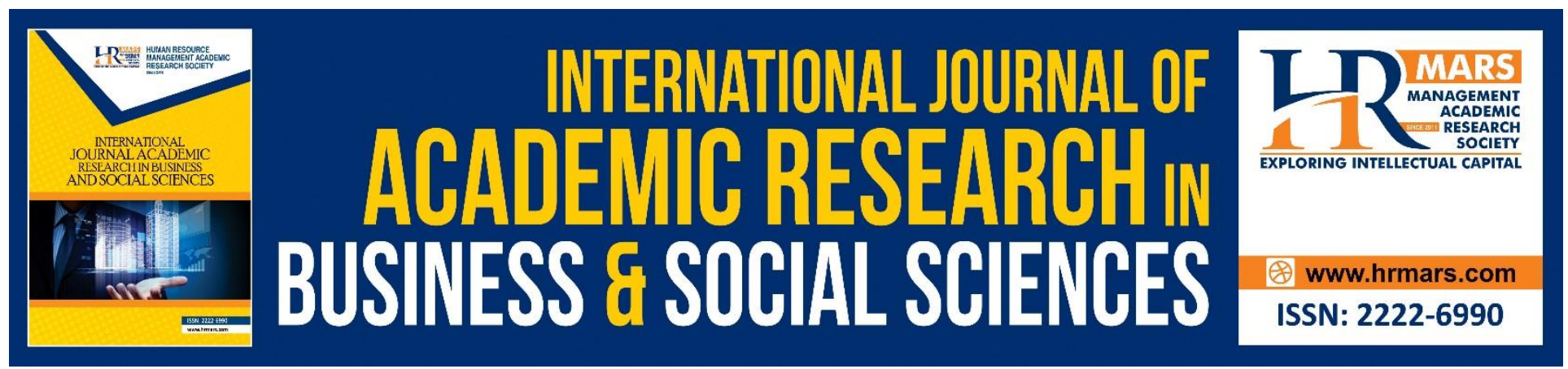

\title{
The Role of Socio-Political Environment in Business Success: A Case of Small Businesses in Uganda
}

\author{
Olema Hamiza \\ Makerere University Business School, Kampala, Uganda \\ Email: holema@mubs.ac.ug \\ Takwi Mbah Francis \\ Ph.D, ICT University USA, Cameroon Campus, Cameroon \\ Email: frankmbah@yahoo.com \\ Taban Rashid \\ Makerere University Business School, Kampala, Uganda \\ Email: trashid@mubs.ac.ug
}

\begin{abstract}
This study focused on the relationship between Socio-political environment and business success in Uganda. The research axiology is value free and the approach is deductive. Data were sourced using structured questionnaire survey consisting of 92 SMEs registered with the Uganda Registration Services Bureau (URSB). Research outcomes revealed that Socio-political environment is a precursor of business success.

The analysis of the study is deterministic and findings are hypothetical. The research design prohibits studying business success using exploratory views. In addition, the data collection tool was standardized questionnaire design, and operationalized using quantitative procedures. Application of an in-depth interview could have given profound insights of the studied phenomenon.

The practical effects of this study are that: entrepreneurs should acclimatize themselves with social and political factors surrounding their businesses to enhance their survival and growth. Scholarly presentations on the effects of Socio-political environment on business success, have attracted little scholarly attention in the past years. This study is therefore of momentous contribution in this area of research.
\end{abstract}

Keywords: Role, Small Business, Socio-Political Environment, Business Success, Uganda

\section{Introduction}

Small businesses in Uganda, like in other parts of the world play a central role in the world economy. Small businesses irrefutably remain critical to the development of any nation's economy as they are an excellent source of employment generation, help in development of local technology and develop 
INTERNATIONAL JOURNAL OF ACADEMIC RESEARCH IN BUSINESS AND SOCIAL SCIENCES Vol. 10, No. 10, 2020, E-ISSN: 2222-6990 @ 2020 HRMARS

indigenous entrepreneurs (Erdem and Erdem, 2011; Alaye-Ogan, 2012). With $80 \%$ of small businesses located in urban areas, they contribute approximately 75 percent of the gross domestic product (GDP) and employ quite a big number of people (Osunsan \& Sumil, 2012; Sands, 2012; Olutayo, 2015). This signifies their undisputed role in the economic development. The importance of small businesses to the citizens' standard of living through income generation and the nation's general growth cannot be overemphasized (Yazdanfar \& Öhman, 2015).

A Small business in Uganda is defined as an enterprise employing a minimum of 5 people and a maximum of 50 people, with annual sales turnover of maximum 360 million Uganda shillings and total assets of maximum 360 million Uganda shillings (MOFPED, 2017). According to the Uganda Small Scale Industries Association, Small businesses are spread across all sub-sectors of the economy viz-aviz manufacturing, construction, hotels and restaurants, education, wholesale and retail trade. Small business success is the effort expended by a business in achieving its objects of financial wellbeing, customer and/or stakeholder satisfaction, profitability, growth and development (Mark \& Nwaiwu, 2015). Biobele (2009); Walabyeki (2015); Kappel and Never (2017) maintain that business success depends to a greater extent on the socio-political environment of the host country. According to these scholars, socio-political environment refers to forces and issues emanating from the social and political decisions, which are capable of altering the expected outcome and value of a given economic action, by changing the probability of achieving business objectives. Ibeto (2011) described the sociopolitical environment as factors arising from changes in the society and the government policies which influence the ability of economic entities in achieving their goals.

Significant studies have been concluded by local researchers concerning factors affecting businesses in Uganda. The studies include: Wanzu (2018) studied e-commerce and growth of Small and Medium Enterprises (SMEs) in Uganda. Elmarie et al., (2014) conducted a study on the influence of potential outcomes of corporate social responsibility engagement factors on SME performance. While Turyahebwa (2015) investigated the effect of financial management practices on business performance of SMEs in Western Uganda. Nangoli et al., (2013) examined inadequate supervision, insufficient managerial skills and small business failure. Mutesigensi (2017) studied the relationship between cash flow and survival of SMEs in Arua District, Western Nile Region, Uganda. It is however particularly relevant to note that none of these studies specifically sought to examine the effect of sociopolitical environment on small business success. Kappel and Never (2017), who are a notable exception studied how the political economy impacts micro and small enterprise development in Uganda and conclude that the system of favouritism prevailing in Uganda's political economy disproportionally affects the business sector, impacting the country's economic development to some extent as well. However, Kappel and Never this study only provides a partial explanation as it ignores the social environment.

\section{Research Problem and Motivation}

Business success in Uganda has remained a dream than reality. According to Uganda Bureau of Statistics (2015), only $30 \%$ of the small businesses in Uganda live to celebrate their 3rd birthday because their performance is characterized by high costs of operation, pitiable quality of products, dwindling sales, low profit margins, stagnant growth and expansion, thus an indication of unsuccessful business. Small businesses in Uganda operate in a dynamic socio-political environment 
INTERNATIONAL JOURNAL OF ACADEMIC RESEARCH IN BUSINESS AND SOCIAL SCIENCES Vol. 10, No. 10, 2020, E-ISSN: 2222-6990 @ 2020 HRMARS

characterized by decline in morals manifested by rampant corruption, favouritism, personal and corporate greed, materialism, high taxation, inflationary tendencies, campaigns against domestic products, unjust legislation, regime changes, terrorism and wars (Griffen, 2005). This raises the question among others, what is the impact of socio-political environment on the success of small businesses given the fact that small businesses are sensitive to the quality and changes of the environment they operate in (Veliu et al., 2018; Cepel et al., 2018; Adair \& Adaskou, 2018). Yet, small businesses are seen as a driving force for the promotion of an economy. This state of affair is worrying and requires an urgent investigation. The drive of this study therefore is to establish the impact of sociopolitical environment on the success of small businesses in Uganda.

\section{Research Objectives}

- To establish the relationship between social environment and business success

- To examine the relationship between political environment and business success

- To find out the combined effect of social and political environment on business success

\section{Research Questions}

- What is the relationship between social environment and business success?

- Is there a relationship between political environment and business success?

- What is the combined effect of social and political environment on business success?

\section{Justification of the Study}

This study has both theoretical and practical contributions. Theoretically, scholars and academicians will find this study an invaluable source of reference material for future studies and subsequent discussions in the area. Practically, this study will be helpful to business owners and/or managers who can use the findings of the study to improve business success. The study also provides important insights that allow policy makers such as town clerks, mayors, ministers for trade and industry understand the impact of sociocultural aspects, government policies, rules and regulations on business success.

\section{Literature Review \\ Conceptual literature}

No business organization can operate successfully in isolation without dependence on supportive institutions, variables and factors (Oginni, 2010) i.e. business organization exists and operates within an environment where there is complex interplay in terms of activities as well as networks of relationship between and among human resources, material resources and other systems. Hence, firm must develop a plan that will help it to cope with the various environmental forces. Thus, the success of every business depends on adapting itself to the environment within which it functions (Oluremi and Gbenga, 2011). Environment is expressed as the sum total of the external forces that influences individuals, businesses and communities (Oginni and Faseyiku, 2012). According to Walabyeki, (2018) the environment refers to all external forces, which have a bearing on the functioning of business.

\section{Types of Environment}

According to Adebayo et al., (2015), environment can be divided into two namely; internal and 
INTERNATIONAL JOURNAL OF ACADEMIC RESEARCH IN BUSINESS AND SOCIAL SCIENCES Vol. 10, No. 10, 2020, E-ISSN: 2222-6990 @ 2020 HRMARS

external environment. The internal environment is made up of variables or factors that organization has control over and can easily manipulate to suit its purpose as may be dictated by the prevailing circumstances such as capital, personnel, profit, procedure, policy, structure, objective etc. The external environment is made up extraneous variables or factors which are outside the control of the organisational management and cannot be manipulated such as technology, politics, and government legislation, economic, socio-cultural and physical factors (Arasti et al., 2012). In this study, we among others focused on the socio-political variables, a component of the external environment.

Social-cultural Environment: it refers to people's attitude to work and wealth; role of family, marriage, religion and education; ethical issues and social responsiveness of business. Socially built reality is when individuals create a social framework for themselves and consequently develop it into an effective reality that shapes and influences their behavioral pattern (Berger and Luckman, 1966). Social system and culture of people are what mix-up to form the Socio-cultural Business Environment and consequently the entrepreneurs become moulded by it (Azim, 2008). The socio-cultural environment also refers to the set of basic common values which contribute to shaping the behaviour of people in a society and has a significant degree of influence on the entrepreneurial intention of individuals (Boggs, 2004; Inglehart, 1997). People acquire their shared characteristics and pattern of behaviour through socialization processes which involves factors like education, religion and family background. These dimensions happen to be the most prominent in describing the socio-cultural environment (Yeboah, 2014).

Political Environment: refers to influence exerted by the three political institutions viz., legislature executive and the judiciary in shaping, directing, developing and controlling business activities (Muhlbacher, Leihs, \& Dahringer, 2006). As defined by Robert (2016), a political environment is a "persistent pattern of human relationship that involves, to a significant extent, control, influence, power, or authority. The political environment also refers to the actions taken by the government, which potentially affect the daily business activities of any business or company. The political systems of the countries being served or being considered by an international marketer are an important part of the firm's macro environment.

\section{Business Success}

Business success concept is an incomprehensible one. This is because debate regarding the contents of success and way of defining it is always open, which is confirmed and emphasized by many authors, like Brush and Wanderwerf (1992); Brooksbank et al., (2003); Rogof et al. (2004); Perren, (2000), Curran, Kitching \& Lightfoot (2000); Jarvis et al. (2000) and Jennings and Beaver (1997). Accordingly, we can find explanations that success is a specific aspect of performance or is identified with high performance. Some of them recognize success in growth and profitability, but this aspect has significant shortcomings in the field of small businesses where goals do not coincide, comparison and a real success statement are difficult to be presented. Financial indicators are simple for success definition and statement, but they can ignore the possibilities of alternative criteria for success definition, based mainly on personal goals of owners/entrepreneurs/managers.

In addition, contrary to the current conviction and significant part of economic theory, money and indifference of financial realization are not significant for engagement of individuals, responsibility and the independence of style and life quality to which owners/managers of small enterprises can 
INTERNATIONAL JOURNAL OF ACADEMIC RESEARCH IN BUSINESS AND SOCIAL SCIENCES Vol. 10, No. 10, 2020, E-ISSN: 2222-6990 @ 2020 HRMARS

aspire. All this indicates significant complications and aggravating circumstances in defining and measuring success of small enterprises, mostly because of goals of owners/entrepreneurs/managers. In business, an enterprise can be considered successful if it realizes the optimal level of performance regarding growth and development. However, it is noticeable for small businesses, although rarely, and only in the conditions of strong connection between job and owners, that personal success is identified with business success, while in other cases nonfinancial criteria and the lifestyle are far more significant. From the foregoing debate, we infer business success as the ability of a business in achieving its objects of financial wellbeing, customer and/or stakeholder satisfaction, profitability, sales volume and growth (Mark \& Nwaiwu, 2015).

\section{Conceptual Model}

The conceptual framework relates socio-cultural environment, political environment to business success. The dependent variable is business success, while the independent variables are social environment and political environment as depicted in figure 1 :

INDEPENDENT VARIABLES

DEPENDENT VARIABLE

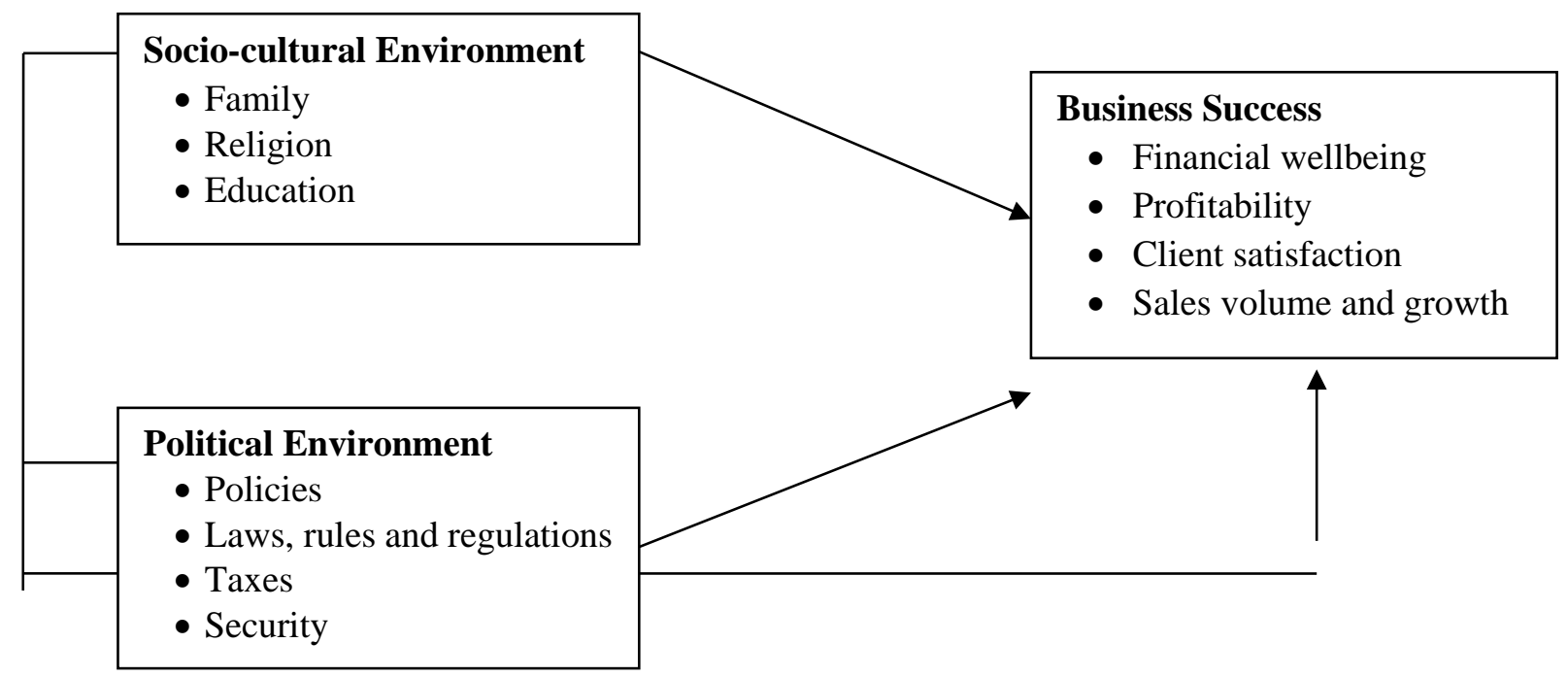

Figure 1: Effect of Socio-Political Environment on Business Success

Source: Adopted and modified from Yeboah (2014); Muhlbacher, Leihs, and Dahringer (2006); Robert (2016); Mark and Nwaiwu (2015).

\section{Theoretical Framework}

The socio-political environment has been grounded in many theories, some of them complementary and others are contradictory, but for the purposes of this study, the following theories are analyzed: The socio capital theory (Karl Marx, Emile \& Max Weber, 1864), the institutional theory (Powell \& DiMaggio, 1991) and business network theory (Pfeffer \& Salancik, 1977).

The proponents of social capital theory claim that social norms, values and beliefs interact with economic growth and development in many ways and, hence, are critical in understanding economic behaviour (Karl Marx, Emile \& Max Weber, 1864). Social capital embodies cultural traits of a society and is considered as source of wealth (Putnam, 1993; Fukuyama, 1995). The differential impact of 
INTERNATIONAL JOURNAL OF ACADEMIC RESEARCH IN BUSINESS AND SOCIAL SCIENCES Vol. 10, No. 10, 2020, E-ISSN: 2222-6990 @ 2020 HRMARS

norms, values, and beliefs on trust, networks, and institutions is the basis of social capital (Fukuyama, 2001). Researchers have uncovered the role of social capital in economic progress and sustainable development (Putnam, 1993; Knack and Keefer, 1997; Sabatini, 2006). Granovetter (1985) argues that most economic behaviours are embedded in social networks. Social capital plays a significant role in providing access to more information, increasing social cohesion, better civic engagement, reducing opportunistic behaviour, boosting political participation, government responsiveness and efficiency, reducing transaction costs, providing insurance against risk and uncertainties, and solving collective actions problems (Coleman, 1990; Putnam, 1993; Fukuyama, 1995; Woolcock and Narayan, 2000; Lin, 2001; Paxton, 2002; Welzel et al., 2005). The Relevance of the social capital theory to this study is that it highlights the positive and productive aspects of sociability. However, the main criticism of social capital theory is that it is not capital, it falls short of being a form of capital and it is widely accepted that social capital can have positive and negative consequences.

Another important theory is the institutional theory of Powell \& DiMaggio 1991. The institutional theorist asserted that the environment in any institution highly influences the formal structure development even more than market pressures. At its heart, institutional theory seeks to explain the isomorphism of organizational fields specifically pertaining to institutional rules, norms and requirements. Organizations that conform to these institutional norms become "optimal, if not efficient, and they prolong their survival by making g use of these norms;" therefore, it minimizes the risk of organizational death as Baum and Olivier (1991) pointed out in their work. This explains why organizations must have strong ties with external constituents for gaining their objectives. The strength of this perspective today may flow from the fact that that the world is awash in rules and requirements in every sector, industry, and nation. From an institutional view, organizations in their very structures communicate symbolically with their environments, absorbing information from the environment and signaling their conformity to established norms and values (Scott \& Meyer, 1983, p. 140).

The relevance of institutional theory to this study is that, businesses absorb government policies and structures to signal to their environments that they are legitimate; legitimacy, in turn, serves as a symbolic resource for organizations. DiMaggio (1988) asserted that "new institutions arise when organized actors with sufficient resources (institutional entrepreneurs) see in them an opportunity to realize interests that they value highly" (p. 14). However, Institutional theory is often criticized as theoretically imperialistic; that is, it purports to encompass and explain everything about organizations. Thus, all external forces are commonly seen as institutional, and all behavior in organizations is held to be a manifestation of institutional forces.

Another theory of relevance to this study is the business network theory (Pfeffer \& Salancik, 1977). A business network can be defined as "a set of connected exchange relationships between firms" (Bernal, Burr \& Johnsen, 2002, p.5). Actors in a network are defined by activities they perform and resources they hold. This theory is premised on the impact of macro environment on business success. The theory stipulates that entrepreneurs may possess some ideas and skills. But, for the purpose of starting up and continuing a business, entrepreneurs further need to obtain most resources from outside his/her external environment through business networks, an assumption that an individual business is dependent on resources that other actors possess (Hollendsen, 1998). This 
INTERNATIONAL JOURNAL OF ACADEMIC RESEARCH IN BUSINESS AND SOCIAL SCIENCES Vol. 10, No. 10, 2020, E-ISSN: 2222-6990 @ 2020 HRMARS

implies that the environment is not faceless, atomistic or within the control of the organization, but rather is enacted as the business organizations' interdependent relationships are created through interactions and even constitutes the organization. Through these relationships, an organization has direct and indirect access to embedded resources and the network thereby contributes to the organization's competitive advantages. Thus, the more resources an organization can access through the networks, the more power and influence the organization has. "A business organization without its interactive environment loses its identity" (Håkansson \& Snehota, 1989:192). Accordingly, entrepreneurial process involves gathering of scarce resources from external environment. Entrepreneurs usually obtain these resources through their networks (Dodd, et al., 2002). Existing literature suggests that networks of entrepreneurs are really an opportunity set, which help entrepreneurs to access both tangible and intangible resources.

The relevance of this theory in this study is that through exchanges with other actors in the environment, small business managers have access to information, large pool of resources, business opportunities and markets that enhances their survival, success and growth. The theory also demonstrates the importance of long-term relationships with customers, suppliers and other actors (Björkman and Forsgren 2000; Hadley and Wilson 2003) and external influences in firms' internationalization process (Ford 1998). For example, acquiring necessary resources and contacts would be difficult without having long-term network partners (Chetty \& Wilson 2003). However, the theory might be less suitable for explaining radical strategic changes like closing down of some units and/or actors (Andersson, 2002).

Table 1. Summary of Theories on which the study is anchored

\begin{tabular}{|l|l|l|l|l|l|}
\hline Theory & Authors & Year & $\begin{array}{l}\text { Gist of the } \\
\text { theory }\end{array}$ & Relevancy & Limitation \\
\hline SCT & $\begin{array}{l}\text { Karl Marx, } \\
\text { Emile \& } \\
\text { MaxWeber, }\end{array}$ & 1864 & $\begin{array}{l}\text { Social norms, } \\
\text { values and } \\
\text { beliefs. }\end{array}$ & $\begin{array}{l}\text { Highlights the } \\
\text { positive and } \\
\text { productive aspects } \\
\text { of sociability. }\end{array}$ & $\begin{array}{l}\text { Has both positive } \\
\text { and negative } \\
\text { consequences. }\end{array}$ \\
\hline IT & $\begin{array}{l}\text { Powell \& } \\
\text { DiMaggio }\end{array}$ & 1991 & $\begin{array}{l}\text { Isomorphism of } \\
\text { institutional } \\
\text { rules, norms and } \\
\text { requirements. }\end{array}$ & $\begin{array}{l}\text { Businesses should } \\
\text { absorb gov't } \\
\text { policies and rules } \\
\text { to signal legitimacy }\end{array}$ & $\begin{array}{l}\text { Neglects other } \\
\text { forces besides } \\
\text { institutional forces. }\end{array}$ \\
\hline BNT & $\begin{array}{l}\text { Pfeffer \& } \\
\text { Salancik, }\end{array}$ & 1977 & $\begin{array}{l}\text { A business is } \\
\text { dependent on } \\
\text { resources that } \\
\text { other actors } \\
\text { possess. }\end{array}$ & $\begin{array}{l}\text { Exchanges with } \\
\text { other actors } \\
\text { creates large pool } \\
\text { of resources for the } \\
\text { business. }\end{array}$ & $\begin{array}{l}\text { Fails to consider } \\
\text { radical strategic } \\
\text { changes such as } \\
\text { close down of other } \\
\text { actors. }\end{array}$ \\
\hline
\end{tabular}

\section{Empirical Literature and Hypotheses}

\section{Socio-cultural Environment and Business Success}

Socio-cultural business environment is integral to industrial and economic well-being of entrepreneurship in general and entrepreneurs in specific terms. People acquire their shared characteristics and pattern of behaviour through socialization processes which involves factors like 
INTERNATIONAL JOURNAL OF ACADEMIC RESEARCH IN BUSINESS AND SOCIAL SCIENCES Vol. 10, No. 10, 2020, E-ISSN: 2222-6990 @ 2020 HRMARS

education, religion and family background. These dimensions happen to be the most prominent in describing the Socio-cultural Business Environment (Yeboah, 2014). This paper is set to study the impact of Education, Religion and Family background on business success.

In recent times, research attention has been focused more on the factors that aid entrepreneurial activities by developing models that depict the relevance of education, past experience and prior knowledge (Shane, 2000). The role of education in entrepreneurship, the contribution it gives to entrepreneurs and their success only came to limelight recently (Kuip and Verheul, 2004). Naturally, all humans possess some degree of entrepreneurial spirit which amounts to intention to become entrepreneur (Solomon, 1989). Such naturally possessed entrepreneurial tendencies could be unleashed through acquiring education (Schultz, 1980). Self-employment becomes attractive with increase in educational level. Managerial ability of individuals is enhanced and polished through acquiring education and consequently influences the tendency of them becoming an entrepreneur (Lucas, 1978; Kransniqi, 2009).

Levent Altinay and Catherine L. Wang in the year 2011 studied the influence of an entrepreneur's socio-cultural characteristics on the entrepreneurial orientation of small firms. In the study data was gathered through 139 face-to-face structured interviews with Turkish ethnic entrepreneurs in London, UK. Part of the findings of the work was that educational attainment of an entrepreneur makes a positive impact on a firm's entrepreneurial orientation. Educational attainment equips business owners with the skills and reflective mindsets of understanding customers and responding to their needs. An increase in education of people and favourable economic realities have aided entrepreneurial success (Garba et al., 2013).

Additionally, different streams of literature have reported the popularity recently gained by the study of relationships between religion, business and economic growth (Galbraith and Galbraith, 2007). Religious beliefs to a large extent are positively related to other socio-economic factors which are instrumental to economic growth and they include education, self-esteem, family unit and life expectancy and so on (Barro and McCleary, 2003). Religion is one of the leading factors that mould economic consciousness. Religion is one of the factors that determine the basic values and beliefs of people. In essence, it explains the extent to which individuals or group take entrepreneurship as valuable and a career (Bwisa and Ndolo, 2011; Garba et al., 2013).

Religion naturally affects personal values and pattern of behaviour like encouraging honesty, hard work, perseverance and improving general ethical standards (Altinay and Wang, 2011). Society deduces meaning to its ethical structures through religion and also determines whether or not to encourage certain behaviours (Dodd and Seaman, 1998). Adherence to religious teachings and practices invariably expose individuals to new behavioural patterns which alter their life style in virtually all manners (Nikolova and Simroth, 2013). Economic growth is largely moved by religion from the angles of belief, practices, governmental influences etc (Barro and Mc Cleary, 2003).

Surprisingly, researchers have been oblivious of the gigantic and important role of family background in building entrepreneurial intention and consequently, business success. Family is an institution where individuals first imbibe cultural codes from (Kalkan and Kaygusuz, 2012). The values and 
behaviour pattern exhibited within the family are key in creating and nurturing support for potential entrepreneurs in their bid to actualize their dream of owning a business of their own or doing whatever they deem as "profitably" never done hitherto (Kuratko, 1989). The family is regarded as a focused unit within which entrepreneurial traits are spread and encouraged especially by the young members in the midst of the elderly ones. The traits imbibed from elementary life of an individual are carried on and eventually they end up influencing what the person becomes in future.

The findings of Crant (1996) revealed that having entrepreneurial parents impacts positively on entrepreneurial Intention. Azam (2010) studied the variables contributing to the growth of women owned enterprises in Islamic Republic of Pakistan from the perspectives of personal resources, firm's characteristics, human resource strategy and favorable women friendly social values and cultural traditions. Statistical analysis and in-depth interviews confirmed that women entrepreneur's personal resources and social capital have a significant role in their business growth. It further discovers that moral support of immediate family, independent mobility, and being allowed to meet with opposite gender play a decisive role in both sales and employment growth of women owned enterprises in an Islamic country like Pakistan. Enough evidence has been established by past researches that Education, Religion and Family background which when put together form the Sociocultural Business Environment all have positive impact on Entrepreneurial success. In general, we can hypothetically state that;

\section{H1. The socio-cultural environment positively influences business success}

\section{Political Environment and Business Success}

The political environment is one of the less predictable elements in business's environment. The relationship between business firms and political organizations contains two presumptions; 1) weakening and change of the coercive behavior or 2) strengthening and change of the supportive behavior. The political initiatives are the following: new regulations or directives, changes to existing rules and regulations, and re-classification of existing rules, regulations, or directives. Ibeto (2011) posit that regulatory changes have the potential to promote or inhibit market competition, social risks often have political bases and responses, and political mismanagement can turn natural or human-made events into catastrophes. According to Walter (2014), the implication of political environment to a business is that the risk emanating from it is a measure of likelihood that political events may complicate its pursuit of earnings through direct impacts (such as taxes or fees) or indirect impacts (such as opportunity cost forgone).

Political factors can impact a business by making the market environment more or less friendly for that business. Typically, governments have a great deal of power over businesses and many times, there is not much that businesses can do about it. Political factors can impact businesses in various ways. These external environmental factors can add in a risk factor which can lead to a major loss in business (Ahsan, 2018). These factors can change the entire results and hence, companies should be able to deal with both local as well as international political outcomes. In addition to this, political factors not only have a direct impact but, it also impacts other factors as well which can have a significant effect on the business and its operating environment. According to Zvirbule and Vilika (2012), with a change in administration policies, there arise political factors that can change the entire 
INTERNATIONAL JOURNAL OF ACADEMIC RESEARCH IN BUSINESS AND SOCIAL SCIENCES Vol. 10, No. 10, 2020, E-ISSN: 2222-6990 @ 2020 HRMARS

business scenario. These changes can be economic, legal or social and can include the following factors:

Tax and economic policies: Increasing or decreasing rate of taxes is a good example of a political component. Government regulations may raise the tax rate for some businesses and can lower the same for others due to specific reasons. This decision will directly impact businesses. This is why maintaining a strategy which can deal with such situations is very important.

Political stability: Lack of political stability within a country can significantly impact the operations of a business. This can especially be true for businesses that are operating on the global scale. For instance, a hostile takeover can take over a government. Eventually, such a situation will lead to looting, riots and general disorder within the environment. Such situations can disrupt business operations and activities which can have a major impact on its bottom line.

Foreign Trade Regulations: Every business has a need to expand business operation to other countries. However, political background of a country influences the desire for a business to expand its operations. Tax policies that are particularly controlled by the government can induce a particular business to expand operations in different regions whereas; other tax policies can hinder the process of business expansion for some industries. Government initiatives, which have been designed to support local businesses, might work against international companies when the question is of their competitiveness in a foreign region.

Employment Laws: Employment laws are made to protect the rights of employees and include every aspect of employer/employee relationship. Employment law is an aspect that is very complex and involves several pitfalls as well. When businesses are in touch with the latest developments in this law, they can manage to take their business in the right direction however, those who get it wrong needs to be completely prepared for the expensive results it will generate. In modern corporations, employees are almost $98 \%$ of the company for the accomplishments or lack thereof and any changes within employment law will, of course, have a great impact on the business operations.

In a nutshell, the political environment of a country impacts business both negatively and positively. The Political environment can change because of the policies and actions of the prevailing government at every level, federal to local level and cause the business to suffer losses or compromise over its profit stream. It is very important that a business should plan for the variability in the policies and regulations of the government to maintain a stable business environment. Therefore, the following hypothesis is proposed:

$\mathrm{H} 2$ : Political environment positively and significantly affects business success

H3: Both socio-cultural and political environment have an effect on business success

\section{Research Methodology}

This study used a descriptive survey design. The target population was 120 small businesses registered with the Uganda Registration Services Bureau (URSB). The businesses are categorized into manufacturing, construction, hotels and restaurants, education, wholesale and retail trade. A sample 
INTERNATIONAL JOURNAL OF ACADEMIC RESEARCH IN BUSINESS AND SOCIAL SCIENCES Vol. 10 , No. 10, 2020, E-ISSN: 2222-6990 @ 2020 HRMARS

size of 92 small businesses based on Krejcie and Morgan (1970) was used. The respondents included owners/Managers, Procurement/purchasing officers, warehouse/store Managers, Logistics officers, sales and marketing officers who are responsible for production/operations management of the businesses and have knowledge in the subject matter. Primary data were collected using a questionnaire anchored on a five-point Likert scale ranging from strongly disagree to strongly agree with close-ended items. Data was analyzed using descriptive and inferential statistics.

Although the study provides some interesting findings and makes important contributions to sociopolitical environment and business literature, several potential limitations are worth noting. Firstly, a cross-sectional approach was undertaken. This approach prohibits studying the sequential aspects of contractor performance. Secondly, the data collection instrument that was used in this study was a standardized questionnaire and quantitative in nature. The use of qualitative studies with in-depth interviews could have given more insights. Lastly, this study examined socio-political environment from the entrepreneurs view point. Future research on socio-political environment from clients and civil servants' point of view is called for.

\section{Analysis and Results}

Descriptive Statistics

Results revealed that most of the small businesses are owned by individuals (70\%), compared to family members, partners and community-based associations that account for only $30 \%$. (52\%) of the businesses have lived for a period of between 1 to 6 years. As regards the type of industry, 51\% are whole and retail businesses, an indicative of small businesses. Majority of the businesses (84\%) have employed between 5 to 15 workers. And $57 \%$ of the small businesses have invested a capital of 10 to 20 million Ugandan shillings.

\section{Reliability and Validity Tests}

We tested for reliability of the questionnaire using Cronbach's $\alpha$ coefficient. Cronbach (1951) requires a Cronbach's $\alpha$ coefficient of at least 0.7 and above and Cronbach's $\alpha$ values for this study were all above 0.7 and thus the instrument was reliable. Item analysis was done to check whether the items in the instrument were correct and a pre-test was carried out using focus experts to check for validity. Results from experts were 0.68 and 0.82 respectively. This showed that the instrument was very relevant and valid.

\section{Correlation Results}

We used Pearson correlation coefficient to establish relationships between the study variables as hypothesized from literature review. The correlation results are displayed in table 2 . 
INTERNATIONAL JOURNAL OF ACADEMIC RESEARCH IN BUSINESS AND SOCIAL SCIENCES Vol. 10, No. 10, 2020, E-ISSN: 2222-6990 @ 2020 HRMARS

Table 2. Correlation coefficients

\begin{tabular}{|l|l|l|l|l|l|l|l|l|l|l|}
\hline Variables & FML & REL & EDU & POL & LRR & TXS & SEC & GSCE & GPLE & BSS \\
\hline FML & 1 & & & & & & & & & \\
\hline REL & $.451^{* *}$ & 1 & & & & & & & & \\
\hline EDU & $.327^{* *}$ & $.238^{*}$ & 1 & & & & & & & \\
\hline POL & .036 & .121 & .161 & 1 & & & & & & \\
\hline LRR & .096 & $.364^{* *}$ & $.387^{* *}$ & $.580^{* *}$ & 1 & & & & & \\
\hline TXS & .032 & $.248^{*}$ & .092 & $.529^{* *}$ & $.650^{* *}$ & 1 & & & & \\
\hline SEC & .056 & $.270^{*}$ & $.238^{*}$ & $.491^{* *}$ & $.636^{* *}$ & $.694^{* *}$ & 1 & & & \\
\hline GSCE & $.801^{* *}$ & $.734^{* *}$ & $.707^{* *}$ & .140 & $.372^{* *}$ & .160 & $.247^{*}$ & 1 & & \\
\hline GSCE & .066 & $.306^{* *}$ & $.264^{*}$ & $.757^{* *}$ & $.862^{* *}$ & $.868^{* *}$ & $.853^{* *}$ & $.279^{*}$ & 1 & \\
\hline BSS & $.341^{* *}$ & $.360^{* *}$ & $.357^{* *}$ & $.278^{*}$ & $.468^{* *}$ & $.354^{* *}$ & $.467^{* *}$ & $.471^{* *}$ & $.473^{* *}$ & 1 \\
\hline
\end{tabular}

* Correlation is significant at the 0.05 level $(p<0.05)$.

** Correlation is significant at the 0.01 level $(p<0.01)$.

Results in table 2 revealed positive and significant relationship between socio-cultural environment $\left(.471^{* *}\right)$, political environment $\left(.473^{* *}\right)$ and business success. Specifically, the results denote solid association of laws and regulations with business success $\left(r=.468^{* *}\right)$, national security with business $\left(r=.467^{* *}\right)$, Taxes to business success $\left(r=.354^{* *}\right)$, and government policies $\left(r=.278^{*}\right)$ as were education to business success $\left(r=.357^{* *}\right)$, family to business success $\left(r=.341^{* *}\right)$, and religion to business success $\left(r=.277^{*}\right)$.

\section{Regression results}

The general objective of this study was to assess whether business success can be influenced by the socio-cultural environment, hence the need to investigate the existence of a causal relationship between the study variables. This was done by running a multiple regression analysis to ascertain whether socio-cultural environment constructs cause variations in business success. The results are summarized in Table 3.

Table 3. Regression model summary coefficients

\begin{tabular}{|c|c|c|c|c|c|c|c|}
\hline \multicolumn{8}{|c|}{ Coefficients $^{\mathrm{a}}$} \\
\hline \multirow[t]{2}{*}{ Model } & \multicolumn{2}{|c|}{$\begin{array}{c}\text { Unstandardized } \\
\text { Coefficients }\end{array}$} & \multirow{2}{*}{$\begin{array}{c}\begin{array}{c}\text { Standardize } \\
\text { d }\end{array} \\
\text { Coefficients } \\
\text { Beta }\end{array}$} & \multirow[t]{2}{*}{$\mathbf{T}$} & \multirow[t]{2}{*}{ Sig. } & \multicolumn{2}{|c|}{$\begin{array}{l}\text { Collinearity } \\
\text { Statistics }\end{array}$} \\
\hline & B & Std. Error & & & & Tolerance & VIF \\
\hline (Constant) & .183 & .550 & & .333 & .740 & & \\
\hline $\begin{array}{l}\text { Socio-cultural } \\
\text { environment }\end{array}$ & .511 & .135 & .368 & 3.788 & .000 & .922 & 1.084 \\
\hline \multirow[t]{2}{*}{ Political environment } & .532 & .139 & .370 & 3.816 & .000 & .922 & 1.084 \\
\hline & \multicolumn{7}{|c|}{ R Square $=.348$, Adjusted R Square $=.331, F=2.038$, sig. $=.000$} \\
\hline
\end{tabular}


INTERNATIONAL JOURNAL OF ACADEMIC RESEARCH IN BUSINESS AND SOCIAL SCIENCES Vol. 10, No. 10, 2020, E-ISSN: 2222-6990 @ 2020 HRMARS

Multiple regression analysis shows a model fit of $34.8 \%\left(R^{2}=.348\right)$. This means that $34.8 \%$ business success is explained by socio-political environment. This is a very significant contribution which must not be ignored. The results further indicate that the model significantly and linearly predicted business success $(F=2.038, p=.000)$.

Table 4. Summary of the results of hypotheses testing

\begin{tabular}{|l|l|l|l|}
\hline Label & Hypothesis & $\mathbf{P}$-Value & Decision \\
\hline $\mathbf{H 1}$ & $\begin{array}{l}\text { The socio-cultural environment positively } \\
\text { influences business success. }\end{array}$ & $\mathrm{P}=0.000<0.05$ & Accept \\
\hline $\mathbf{H 2}$ & $\begin{array}{l}\text { Political environment positively and significantly } \\
\text { affects business success. }\end{array}$ & $\mathrm{P}=0.000<0.05$ & Accept \\
\hline $\mathbf{H 3}$ & $\begin{array}{l}\text { Both socio-cultural and political environment have } \\
\text { an effect on business success }\end{array}$ & $\mathrm{P}=0.000<0.05$ & Accept \\
\hline
\end{tabular}

Source: Analysis results

\section{Discussion of Results}

The results revealed a strong positive and significant relationship between socio-cultural environment $\left(.471^{* *}\right)$, political environment $\left(.473^{* *}\right)$ and business success. Specifically, the results denote solid association of laws and regulations with business success $\left(r=.468^{* *}\right)$, national security with business $\left(r=.467^{* *}\right)$, Taxes to business success $\left(r=.354^{* *}\right)$, and government policies $\left(r=.278^{*}\right)$ as were education to business success $\left(r=.357^{* *}\right)$, family to business success $\left(r=.341^{* *}\right)$, and religion to business success $\left(r=.277^{*}\right)$. The findings mean that a positive change in socio-political environment will lead to a positive change in business success. This implies that socio-political environment and business success move in the same direction. Therefore, entrepreneurs should highly value sociopolitical environmental factors such as laws and regulations, national security, religion, education, taxes, family influence and government policies in conducting business.

In relation to the predictive power of the study variables, results have shown that $34.8 \%(\mathrm{R} 2=.348)$ of business success is explained by both socio-cultural and political environment. Specifically, results have shown that the political environment is a significant predictor of business success (Beta .370; $P=.000<0.05$ ), and socio-cultural environment (Beta .368; $P=.000>0.05$ ). This is a very significant contribution which must not be ignored. These findings corroborate with Azam (2010) who confirmed through in-depth interviews that entrepreneur's personal resources and social capital have a significant role in their business growth. Furthermore, the findings are in agreement with Walter (2014), who posits that the political status and changes have the potential to promote or inhibit business success. In respect of the hypotheses one, two and three $(\mathrm{H} 1, \mathrm{H} 2$ \& $\mathrm{H} 3)$, the study accepted $\mathrm{H} 1, \mathrm{H} 2$ and $\mathrm{H} 3$ respectively (Table 4). The study supports the socio capital theory of Karl et al. (1864), the institutional theory (Powell \& DiMaggio, 1991) and business network theory (Pfeffer \& Salancik, 1977) in emphasizing the need for entrepreneurs to integrate the external environment in business activities so as to better business performance.

\section{Conclusion}

This study sought to establish whether business success is influenced by socio-cultural and political environment. Results have shown that $34.8 \%$ of business success is predicted or explained by socio- 
INTERNATIONAL JOURNAL OF ACADEMIC RESEARCH IN BUSINESS AND SOCIAL SCIENCES Vol. 10, No. 10, 2020, E-ISSN: 2222-6990 @ 2020 HRMARS

political environment. This implies that socio-political environment is an important precursor of business success. It is therefore vivacious that entrepreneurs should be considerate of socio-political forces within their environment such as laws and regulations, security, religion, education, taxes, family influence and government policies so as to be successful in business.

\section{Reccomendations}

We therefore strongly recommend that: Social values and norms such as family teachings, religion and education should be upheld and emphasized to the society so as to improve business success. The government of Uganda should maintain a sustained peace in the country, sensitize entrepreneurs on laws and regulations, taxes and government policies to encourage societal confidence and acceptability so as to create a conducive environment for business survival and growth. Entrepreneurs should acclimatize themselves with the relevant social values, and government rules and regulation in order to mutually exist and boost business activities.

\section{Theoretical and Practical Contributions}

Theoretically, the study adds on to the knowledge of socio-political factors like laws and regulations, security, religion, education, taxes, family influence and government policies. Scholars and academicians will also find this study an invaluable source of reference material for future studies in the area as well as for discussions in the field of socio-political environment. Practically, the study will be invaluable to entrepreneurs who can use the findings to improve business success. In the same vain, this study provides important insights that allow government technocrats such as the Lord mayor, Town clerk and the commercial officer to better understand small scale business matters.

\section{References}

Altinay, L., \& Wang, C. L. (2011). The influence of an entrepreneur's socio-cultural characteristics on the entrepreneurial orientation of small firms. Journal of Small Business and Enterprise Development, 18(4), 673-694.

Arasti, Z., Pasvishe, F. A., \& Motavaseli, M. (2012). Normative Institutional Factors Affecting Entrepreneurial Intention in Iranian Information Technology Sector. Journal of Management and Strategy, 3(2), 16-25.

Asika, N. (1991). Research Methodology in the Behavioral Sciences. Lagos: Longman Nigeria. International Business Review, 12 (1), 61-81.

Asiimwe, F. (2017). Corporate governance and performance of SMEs in Uganda. International Journal of Technology and Management, 2(1), 1-14.

Azim, M. T. (2008). Socio-cultural environment for entrepreneurship development in Bangladesh. Journal of Bangladesh Studies, 10(1), 51-60.

Barro, R. J., \& McCleary, R. (2003). Religion and economic growth (No. w9682). National Bureau of Economic Research.

Berger, P. L., \& Luckmann, T. (1991). The social construction of reality: A treatise in the sociology of knowledge (No. 10). Penguin UK.

Björkman, Ingmar and Forsgren, M. (2000), “Nordic International Business Research," International Studies of Management \& Organization, 30 (1), 6-24. 
INTERNATIONAL JOURNAL OF ACADEMIC RESEARCH IN BUSINESS AND SOCIAL SCIENCES

Vol. 10, No. 10, 2020, E-ISSN: 2222-6990 @ 2020 HRMARS

Bwisa, H. M., \& Ndolo, J. M. (2011). Culture as a factor in entrepreneurship development: A case study of the Kamba culture of Kenya. International Journal of Business Management, 1(1), 2029.

Chetty, S. K., and Heather, I. M. W. (2003), "Collaborating with Competitors to

Coleman, J. S. (1988) "Social Capital in the Creation of Human Capital". American Journal of Sociology Supplementary 94: 95-120.

DiMaggio, P. J. (1988). Interest and agency in institutional theory. In L. G. Zucker (Ed.), Institutional patterns and organizations: Culture and environment (pp. 3-22). Cambridge, MA: Ballinger.

Dodd, S., Jack S., and Anderson, A. (2002). Scottish Entrepreneurial Networks in the International Context.

Dynamics in International Marketing, Peter Naudé and Peter W. Turnbull, eds. Oxford: Elsevier, 3-15.

Ford, D. (1998), "Two decades of interaction, relationships and networks," in Network. International Small Business Journal, 20(2): 213-219.

Fukuyama, F. (1995) Trust: The Social Virtues and the Creation of Prosperity. New York: Free Press.

Galbraith, C. S., \& Galbraith, D. M. (2007). An empirical note on entrepreneurial activity, intrinsic religiosity and economic growth. Journal of Enterprising Communities: People and Places in the Global Economy, 1(2), 188-201.

Garba, A. S., Mansor, S. A., \& Djafar, F. (2013). An Exploratory Study on the Constraints for Entrepreneurial Activity: A Case of Micro and Small Enterprises in Kano, Nigeria. Journal of Applied Management and Entrepreneurship, 18(4), 79.

Granovetter, M. S. (1985) "Economic Action and Social Structure: The Problem of Embeddedness". American Journal of Sociology 91: 481-510.

Hadley, R. D., and Heather, I. M. W. (2003), "The Network Model of Internationalisation and Experiential Knowledge," International Business Review, 12 (6), 697-717.

Håkansson, H., \& Snehota, I. (1989). No Business is an island - The network concept of business strategy. Scandinavian Journal of Management, 5 (3), 187-200.

Hollendsen S. (1998) "The network model. From Global Marketing: A market-responsive approach." Prentice Hall Europe, pp. 49-51.

Kalkan, M., \& Kaygusuz, C. (2012). The Psychology of Entrepreneurship. Edited by Thierry BurgerHelmchen, 1.

Levent, B. T., Masurel, E., and Nijkamp, P. (2003). Diversity in entrepreneurship: Ethnic and female roles in urban economic life. International Journal of Social Economics, 30(11), 1131-61.

Lin, N. (2001) Social Capital: A Theory of Social Structure and Action. Cambridge: Cambridge University Press.

Lucas Jr, R. E. (1978). On the size distribution of business firms. The Bell Journal of Economics, 508523.

Nangoli, S., Turinawe, D. D., Kituyi, G. M., Kusemererwa, C., \& Jaaza, M. (2013). Towards Enhancing Business Survival and Growth Rates in LDCs: An Exploratory Study of the Drivers of Business Failure among SMEs in Kampala- Uganda. International Journal of Humanities and Social Science, 3(8).

Pfeffer, J., \& Salancik, G. R. (1978), The external control of organizations resource dependence perspective, Harper \& Row, New York 
INTERNATIONAL JOURNAL OF ACADEMIC RESEARCH IN BUSINESS AND SOCIAL SCIENCES Vol. 10, No. 10, 2020, E-ISSN: 2222-6990 @ 2020 HRMARS

Powell, W. W., \& DiMaggio, P. J. (Eds.). (1991). The new institutionalism in organizational analysis. Chicago, IL: University of Chicago Press.

Scott, W. R., \& Meyer, J. W. (1983). The organization of societal sectors. In J. W. Meyer \& W. R. Scott (Eds.), Organizational environments: Ritual and rationality (pp. 129-153). Beverly Hills, CA: SAGE.

Solomon, G. T. (1989). Entrepreneurs: What they're really like. Vocational Education Journal, 64(8), 42-44.

Turyakira, P. (2012). Corporate social responsibility: A competitive strategy for small and mediumsized enterprises in Uganda. Unpublished doctoral thesis, Nelson Mandela Metropolitan University. Uganda Bureau of Statistics (UBOS) (2012). Business Register Update.

Welzel, C., Inglehart, R., and Deutsch, F. (2005) "Social Capital, Voluntary Associations, and Collective Action: Which Aspects of Social Capital Have the Greatest Civic Payoff?" Journal of Civil Society 1(2): 1-26.

Woolcock, M. (1998) "Social Capital and Economic Development: Toward a Theoretical Synthesis and Policy Framework". Theory and Society 27(2): 151-208.

Woolcock, M., and Narayan, D. (2000) "Social Capital: Implications for Development Theory, Research, and Policy". The World Bank Research Observer 15(2): 225-249.

Yeboah, M. A. (2014). Analysis of entrepreneurship: How does culture influence risk-taking in SMEs in the Sekondi-Takoradi metropolis, Ghana. American International Journal of Contemporary Research, 4(2), 131-140.

Zvirbule, B., and Vilika. (2012). Impact of Social Environment on Economic development in the Baltic States\|, Journal of World academy of Science, Engineering and Technology. 